\title{
PSIKOLOGI OLAHRAGA DAN FILSAFAT
}

\author{
Dian Anggraini Kusumajati \\ Jurusan Psikologi, Fakultas Humaniora, BINUS University \\ Jln. Kemanggisan Ilir III No. 45, Kemanggisan/Palmerah, Jakarta 11480 \\ diananggik@binus.edu
}

\begin{abstract}
The awareness that sports was an international science that emerged in the mid of 20th century, and in Indonesia it was officially acknowledged in 1998 by an sport science declaration. The application of psychology in sports was to support the sport talent in a person could be well developed without any constraints in his/her personality. Eksistensialisme is a branch of the Phylosophy that reflects that men always exists in his/her life. Phylosophyy played important role in integrating many science reviews that could be formulated in sports having ontology, episthemology, and axiology dimensions which was in line with other sciences. Sport Psychology and Phylosophy reviews reveal the importance of the "root" of them in order to develop it, as well as to introduce sport psychology in Indonesia.
\end{abstract}

Keywords: sport psychology, philosophy

\begin{abstract}
ABSTRAK
Kesadaran bahwa olahraga merupakan ilmu secara internasional mulai muncul pertengahan abad 20, dan di Indonesia secara resmi dibakukan melalui deklarasi ilmu olahraga tahun 1998. Penerapan psikologi ke dalam bidang olahraga adalah untuk membantu agar bakat olahraga yang ada dalam diri seseorang dapat dikembangkan sebaik-baiknya tanpa adanya hambatan dan faktor yang ada dalam kepribadiannya. Eksistensialisme adalah cabang filsafat yang merefleksikan manusia selalu bereksistensi didalam hidupnya. Filsafat, dalam hal ini dianggap memiliki tanggung jawab penting dalam mempersatukan berbagai kajian ilmu untuk dirumuskan secara terpadu dan mengakar menuju ilmu olahraga dalam tiga dimensi ilmiah (ontologi, epsitemologi dan aksiologi) yang kokoh dan sejajar dengan ilmu lain. Dari pembahasan mengenai psikologi olahraga dan filsafat membuat kita merasakan bahwa pentingnya mengetahui akar keilmuan psikologi olahraga dan dapat lebih mengembangkan olahraga. Selain itu, lebih mengembangkan dan memperkenalkan psikologi olahraga dalam dunia olahraga di Indonesia.
\end{abstract}

Kata kunci: psikologi olahraga, filsafat 


\section{PENDAHULUAN}

Kesadaran bahwa olahraga merupakan ilmu secara internasional mulai muncul pertengahan abad 20, dan di Indonesia secara resmi dibakukan melalui deklarasi ilmu olahraga tahun 1998. Beberapa akademisi dan masyarakat awam memang masih pesimis terhadap eksistensi ilmu olahraga, khususnya di Indonesia, terutama dengan melihat kajian dan wacana akademis yang masih sangat terbatas dan kurang integral. Namun sebagai suatu ilmu baru yang diakui secara luas, ilmu olahraga berkembang seiring kompleksitas permasalahan yang ada dengan ketertarikan-ketertarikan ilmiah yang mulai bergairah menunjukkan eksistensi ilmu baru ini ke arah kemapanan (Pramono, 2003).

Ilmu yang dibutuhkan dalam dunia olahraga adalah psikologi. Psikologi adalah ilmu yang mempelajari perilaku manusia dalam hubungannya dengan lingkungannya, mulai dari perilaku sederhana sampai kompleks. Psikologi olahraga adalah merupakah salah satu cabang ilmu yang relatif baru, yaitu merupakan salah satu hasil perkembangan dari psikologi. Hal ini dapat dijelaskan bahwa sejak akhir abab ke-19 para ahli psikologi telah berusaha menerapkan hasil-hasil penelitian psikologi ke dalam kehidupan sehari-hari. Selanjutnya tumbuh dan berkembang apa yang disebut sebagai psikologi terapan (applied psychology) di berbagai bidang, termasuk salah satunya adalah dalam bidang olahraga.

Ilmu psikologi yang diterapkan ke dalam bidang olah raga yang selalu dikenal sebagai psikologi olahraga. Penerapan psikologi ke dalam bidang olahraga ini adalah untuk membantu agar bakat olahraga yang ada dalam diri seseorang dapat dikembangkan sebaik-baiknya tanpa adanya hambatan dan faktor-faktor yang ada dalam kepribadiannya. Dengan kata lain, tujuan umum dari psikologi olahraga adalah untuk mebantu seseorang agar dapat menampilkan prestasi optimal, yang lebih baik dari sebelumnya.

Psikologi Olahraga mengandung dimensi tindakan dan perilaku manusia, dimana komponenkomponen motorik, kognitif, dan afektif amat berperan dalam menghasilkan berbagai pola gerak yang berbeda. Psikologi olahraga mempelajari berbagai kenyataan psikologis yang dihadapi seseorang dalam konteks kegiatan berolahraga.

Singer (dalam Gunarsa, 2004) mengemukakan secara singkat bahwa Psikologi Olahraga adalah "the science of psychology applied to athletes and athletic situations". Cox (Gunarsa, 2004) mengemukakan bahwa "Sport Psychology is a science in which the principles of psychology are applied in a sport setting”. Psikologi olahraga pada hakikatnya adalah psikologi yang diterapkan dalam bidang olahraga, meliputi factor-faktor yang berpengaruh secara langsung terhadap atlet dan factor-faktor di luar atlet yang dapat mempengaruhi penampilan atlet tersebut. Selain itu, psikologi olahraga berhubungan dengan pengamatan terhadap peristiwa-peristiwa di lingkungan olahraga, deskripsi suatu gejala/ peristiwa, penjelasan mengenai faktor-faktor yang mempengaruhi suatu peristiwa secara sistematis, meramalkan suatu peristiwa atau akibat daripada suatu peristiwa yang dilandasi penjelasan yang sistematis dan terpercaya, serta pengendalian peristiwa atau kemungkinan terjadinya suatu peristiwa (Anshel, 1991).

Pada hakikatnya psikologi adalah ilmu yang mempelajari tentang perilaku yang diperlihatkan oleh seseorang ketika sedang berolahraga, atau disebut penampilannya dalam berolahraga. Dengan demikian jelaslah bahwa olahraga atau tampilannya dalam berolahraga, sangat dipengaruhi oleh adanya faktor psikis seperti meningkatnya stres dalam pertandingan dapat menyebabkan altlet bereaksi secara negatif, baik dalam hal fisik maupun psikis, sehingga kemampuan olahraganya menurun. Mereka dapat menjadi tegang, denyut nadi meningkat, berkeringan dingin, cemas akan hasil pertandingan, dan mereka merasakan sulit berkonsentrasi. Keadaan ini seringkali menyebabkan para atlet tidak dapat menampilkan permainan terbaiknya. Mental yang tegar sama halnya dengan teknik 
dab fisik akan didapat melalui latihan yang terencana, teratur, dan sistematis. Dalam membina aspek psikis atau mental atlet pertama-tama perlu disadari bahwa setiap atlet harus dipandang secara individual yang satu berbeda dengan yang lainnya. Untuk membantu mengenal profil setiap atlet dapat dilakukan pemerikasaan psikologis.

Seperti telah diketahui, psikologi, dan semua ilmu lainnya, merupakan pecahan dari filsafat. Di dalam filsafat, kita juga bisa menemukan refleksi-refleksi yang cukup mendalam tentang konsep jiwa dan perilaku manusia. Refleksi semacam itu dapat ditemukan baik di dalam teks kuno filsafat, maupun teks fisafat modern.

Secara khusus, filsafat bisa memberikan kerangka berpikir yang sistematis, logis, dan rasional bagi para psikolog, baik praktisi maupun akademisi. Seluruh ilmu pengetahuan dibangun di atas dasar logika, dan begitu pula psikologi. Metode pendekatan serta penarikan kesimpulan seluruhnya didasarkan pada prinsip logika.

Salah satu cabang filsafat yang kiranya sangat mempengaruhi psikologi adalah eksistensialisme. Tokoh-tokohnya adalah Soren Kierkegaard, Friedrich Nietzsche, Victor Frankl, JeanPaul Sartre, dan Rollo May. Eksistensialisme sendiri adalah cabang filsafat yang merefleskikan manusia selalu bereksistensi di dalam hidupnya. Jadi, manusia dipandang sebagai individu yang terus menjadi, yang berproses mencari makna dan tujuan di dalam hidupnya.

Sejalan dengan aliran eksistensialisme tersebut, salah satu tokohnya yang bernama Friedrich Nietzsche termasuk filsuf kontroversial yang paling banyak dirujuk sebagai penyumbang tak langsung debat akademis tentang kaitan pemikiran filsafat dan ilmu keolahragaan. Beberapa penulis, seperti Richard Schacht, menyebut "filsafat olahraga Nietzscheian" sebagai istilah penting dalam bahasan ilmiahnya, Nietzsche and Sport, meskipun istilah ini masih perlu dicurigai sebagai terlalu maju dan ahistoris, oleh karena pemikiran lain seperti Hatab (Pramono, 2003) menyatakan bahwa Nietzsche sedikit sekali atau bahkan tidak bicara aktivitas altletik dan olah raga secara langsung. Hatab mengeksplorasi Nietzsche hanya dalam kaitan pemikirannya yang dapat diasosiasikan dan mengarah pada tema keolahrgaan.

Hatab mengeksplorasi beberapa pemikiran Nietzsche seperti will to power, sublimationa, embodiment, spectacle dan play yang terarah pada aktivitas atletik dan event-event olahraga (Pramono, 2003). Dari sini, dapat dimaknai bahwa arah pemikiran yang berhubungan secara historis pada dunia keolahragaan termasuk dalam ekspresi pemikiran filosofis, dan oleh karenanya, ilmu keolahragaan memiliki akar filosofisnya.

\section{Deskripsi Aliran/Tokoh}

Friedrich Nietzsche lahir di Rocken pada tanggal 15 oktober 1844. Kakeknya, Friedrich August Ludwig adalah seorang pendeta. Tahun 1796, kakek Nietzsche dianugerahi gelar doktor kehormatan atas pembelaanya terhadap agama Kristen. Ayah Nietzsche, Karl Ludwig juga seorang pendeta. Awalnya, Nietzsche adalah seorang mahasiswa fakultas Teologi. Namun, pada akhirnya ia keluar karena lebih tertarik pada filsafat. Ia memulai dengan membaca filsafat Schopenhauer. Berawal dari ketertarikannya terhadap Schopenhauer, ia mulai menciptakan karya-karya filologis. Beberapa tahun kemudian ia meluncurkan buku pertamanya, The Birth of Trgedy, yang berisi tentang tragedy Yunani. Setelah buku pertamanya ini, Nietzsche mulai banyak memunculkan pemikiran -pemikiran baru dan juga buku-buku baru. Pemikiran-pemikirannya juga dipengaruhi oleh tokoh-tokoh yang sempat ia temui dalam hidupnya, seperti Richard Wagner, Bismarck, Freud dan Darwin. Buku-buku yang telah ditulis oleh Nietzsche, antara lain The Birth of Tragedy, Human All-Too-Human, The Wanderer and his Shadow, The Gay Science, Thus Spoke Zarathustra, The Good and Evil. 
Filsafat Nietzsche banyak dipengaruhi oleh tokoh-tokoh yang ia kagumi dan para filsuf sebelum dirinya. Selain itu, Filsafatnya juga dipengaruhi oleh unsur filologis yang berisi tentang Yunani. Hal ini dikarenakan oleh ketertarikannya terhadap filologi yang bercerita tentang legendalegenda Yunani. Dalam filsafat Nietzsche dijelaskan bahwa hidup adalah penderitaan dan untuk menghadapinya kita memerlukan seni. Seni yang dimaksud oleh Nietzsche ada dua jenis, yaitu Apolline dan Dionysian. Sehingga Nitzsche mengagumi Richard Wagner yang ikut mempengaruhi gaya filsafatnya.

Pemikiran Nietzsche yang pertama adalah mengenai hidup adalah sebuah penderitaan. Dalam pemikirannya ini, Nietzsche menjelaskan bahwa dalam mengahadapi penderitaan itu, kita harus menggunakan seni. Selain itu, Nietzsche juga menjelaskan mengenai moralitas. Dalam penjelasanya dikatakan bahwa menjadi bermoral adalah menghormati adat istiadat komunitas. Adalah tidak bermoral untuk menghadapi adat istiadat, karena itu akan membahayakan komunitas. Kritianitas di sisi lain tidak bermoral, karena tujuannya adalah membebaskan individu dari beban tradisi Yahudi. Adalah kebenciannya terhadap hokum (Taurat) dan ketidakmampuannya menghormati hukum yang menyebabkan Saulus menjadi Paulus dan menemukan penebusan agung dari dosa asal dengan mengeksploitasi wafat Yesus. Oleh karena hal tersebut, maka moral kristianitas digantikan oleh moral yang berdasar pada kebikan umum.

Pemikiran Nietzsche yang lain adalah mengenai prinsip dalam kehidupan. Dalam pemikirannya ini disebutkan bahwa manusia harus membuat hukum untuk diri sendiri dan tidak melawan realitas. Jika manusia melawan realitas maka kehidupannya akan menderita karena terkadang manusia memiliki keinginan yang berlawanan dengan realitas. Apabila keinginan it uterus dipaksakan, maka manusia harus melawan realitas, sedangkan menurut Nietzsche yang terjadi tidak dapat dihindari. Sehingga untuk melawan realitas adalah sia-sia. Sehingga lebih baik manusia menerima hidup apa adanya dengan lapang dada.

Selain itu manusia harus membuat hukum untuk dirinya sendiri, ini bertujuan agar manusia dapat menjadi majikan atas dirinya sendiri. Dengan membuat hukum untuk dirinya sendiri, manusia dapat mengendalikan dirinya dalam menghadapi kehidupan. Dengan dua prinsip tersebut maka manusia dapat hidup menjadi manusia yang kuat dalam menghadapi hidup yang merupakan penderitaan.

Nietzsche juga menjelaskan bahwa manusia memiliki keinginan untuk berkuasa. Pemikiran ini muncul dengan dipicu oleh kemunculan teori Darwin yang membenarkan tentang kemenangan kaum kuat atas kaum lemah dalam pergulatan demi eksistensi. Selain keinginan untuk berkuasa, Nietzsche juga menyatakan bahwa kelas-kelas sosial dalam masyarakat pada akhirnya akan menjadi sejajar, tidak da yang lebih tinggi dan tidak ada yang lebih rendah. Menurut Nietzsche ini adalah hasil dari Nihilisme. Nihilisme adalah keinginan untuk ketiadaan, yang artinya menghapuskan perbedaan antar kelas dan jenis kelamin.

Nietzsche juga memiliki pemikiran tentang si manusia super, kekuatan dan pengulangan abadi. Si manusia super menurut Nietzsche adalah tingkat tertinggi dari kemanusiaan. Namun, tingkat ini hanya bisa dicapai ketika massa dikorbankan kepada kaum elite. Kekuatan menurut Nietzsche adalah hukum dari suatu masyarakat yang 'sehat'. Masyarakat dianggap sakit bila ia menyerah pada paham 'martabat manusia' dan 'martabat kerja'. Sedangkan pengulangan abadi menurut Nietzsche adalah mengenai kehidupan ini yang sebenarnya terus berulang dari masa ke masa. Namun, Nietzsche tidak menjelaskan kembali mengenai pengulangan abadi dalam buku-buku keluaran terbarunya.

\section{Relevansi Aliran/Tokoh dengan Masalah}

Olahraga, sebagaimana yang dikatakan Schat (1998), seperti halnya seks, terlalu penting untuk dikacaukan dengan tema lain. Ini tidak hanya tentang latihan demi kesehatan. Tidak hanya permainan 
untuk hiburan, atau menghabiskan waktu luang, atau untuk kombinasi dari masud social dan rekreasional. Olahraga adalah aktivitas yang memiliki akar eksistensi ontologism sangat alami, yang dapat diamati sejak bayi dalam kandungan sampai dengan bentuk-bentuk gerakan terlatih. Olahraga juga adalah permainan, senada dengan eksistensi manusiawi sebagai makhluk bermain. Olahraga adalah tontonan, yang memiliki akar sejarah yang panjang, sejak jaman Yunani Kuno dengan arête, agon, pentathlon sampai dengan Olimpic Games di masa modern, di mana dalam sejarahnya, perang dan damai selalu mengawal peristiwa keolahragaan itu. Olahraga adalah fenomena multidimensi, seperti halnya manusia itu sendiri. Mitos dan agama Yunani awal menampilkan suatu pandangan dunia yang membantu perkembangan kesalinghubungan intrinsik antara makna olahraga dan budaya dasar.

Terdorong oleh rasa ingin mencari jawaban tepat terhadap pertanyaan: apakah olahraga merupakan ilmu yang berdiri sendiri, dan sebagai tindak lanjut dari pertemuan sebelumnya, maka diselenggarakanlah pada tahun 1998 di Surabaya suatu Seminar Lokakarya Nasional Ilmu Keolahragaan. Seminar ini mampu melahirkan kesepakatan tentang pendefinisian pengertian olahraga yang dikenal dengan nama Deklarasi Surabaya 1998 tentang Ilmu Keolahragaan, sebagai jawaban bahwa olahraga merupakan ilmu yang mandiri. Sebagai ilmu yang mandiri, olahraga harus dapat memenuhi 3 kriteria: obyek, metode dan pengorganisasian yang khas, dan ini dicakup dalam paparan tentang ontologi, epistemologi dan aksiologi (Komisi Disiplin Ilmu Keolahragaan, 2000). Dari sini, filsafat ilmu muncul sebagai suatu kebutuhan.

Beberapa akademisi dan masyarakat pada umumnya masih kurang yakin terhadap eksistensi ilmu olahraga, khususnya di Indonesia, terutama dengan melihat kajian dan wacana akademis yang masih sangat terbatas dan kurang integral. Namun sebagai suatu ilmu baru yang diakui secara luas, ilmu olahraga berkembang seiring kompleksitas permasalahan yang ada dengan keterkaitanketerkaitan ilmiah yang mulai bergairah menunjukkan eksistensi ilmu baru ini ke arah kemapanan.

Filsafat, dalam hal ini dianggap memiliki tanggung jawab penting dalam mempersatukan berbagai kajian ilmu untuk dirumuskan secara terpadau dan mengakar menuju ilmu olahraga dalam tiga dimensi ilmiahnya (onotlogi, epsitemologi dan aksiologi) yang kokoh dan sejajar dengan ilmuilmu lainnya.

Aspek pertama, ontologi, setidaknya dapat dirunut dari obyek studi ilmu keolahragaan yang unik dan tidak dikaji ilmu lain. Sebagai rumusan awal, UNESCO mendefinisikan olahraga sebagai "setiap aktivitas fisik berupa permainan yang berisikan perjuangan melawan unsur-unsur alam, orang lain, ataupun diri sendiri”. Sedangkan Dewan Eropa merumuskan olahraga sebagai "aktivitas spontan, bebas dan dilaksanakan dalam waktu luang”. Definisi terakhir ini merupakan cikal bakal panji olahraga di dunia "Sport for All" dan di Indonesia tahun 1983, "memasyarakatkan olahraga dan mengolahragakan masyarakat” (Rusli dan Sumardianto, 2000).

Aspek kedua sebagai dimensi filsafat ilmu adalah epistemologi yang mempertanyakan bagaimana pengetahuan diperoleh dan apa isi pengetahuan itu. Ilmu keolahragaan dalam pengembangannya didekati melalui pendekatan multidisipliner, lintasdisipliner dan interdisipliner. Pendekatan multidisipliner ditandai oleh orientasi vertikal karena merupakan penggabungan beberapa disiplin ilmu. Interdisipliner ditandai oleh interaksi dua atau lebih disiplin ilmu berbeda dalam bentuk komunikasi konsep atau ide. Sedangkan pendekatan lintasdisipliner ditandai orientasi horisontal karena melumatnya batas-batas ilmu yang sudah mapan. Ketiga pendekatan seperti multidisipliner, lintasdisipliner dan interdisipliner dalam khasanah ilmu keolahragaan membentui batang tubuh ilmu sebagai jawaban atas pertanyaan apa isi ilmu keolahragaan tersebut.

Aksiologi—aspek ketiga—berkaitan dengan nilai-nilai, untuk apa manfaat suatu kajian. Secara aksiologi olahraga mengandung nilai-nilai ideologi, politik, ekonomi, sosial, budaya dan strategis dalam pengikat ketahanan nasional (KDI Keolahragaan, 2000). Sisi luar aksiologis ini 
menempati porsi yang paling banyak, dibandingkan sisi dalamnya yang memang lebih sarat filosofinya. Kecenderungan-kecenderungan sisi aksiologi keolahragaan ini secara akademis menempati sisi yang tak bisa diabaikan, bahkan cenderung paling banyak diminati untuk dieksplorasi. Ini termasuk dari sisi estetisnya, di mana Randolph Feezell mengulasnya secara fenomenologis, selain dimensi naratifnya (Feezell, 1989). Kemungkinan nilai etisnya, Mieth (1989) membahasnya secara ekstensif dan komprehensif. Ryan dalam Pramono (2003) membahas kaitan olahraga dengan arah spiritualitasnya. Shinabargar (1989) secara sosiologis membahas dimensi feminis dalam olahraga. Yang tersebut di atas adalah beberapa contoh cakupan dimensi ilmu keolahragaan dalam filsafat ilmu, ekstensifikasi dan intensifikasi masih luas menantang.

Bertumbuh suburnya ilmu-ilmu yang berangkat dari dimensi ontologi, epistemologi dan aksiologi, membuktikan bahwa apa yang ditulis oleh Paul Weiss dalam bukunya Sport: A Philosophy Inquiry (1969) bahwa semakin banyak renungan filosofis yang mengarahkan keingintahuan mendalam dan keterpesonaan terhadap olahraga, memiliki daya prediktif, persuasif dan benar adanya. Ini perlu dimaknai secara operasional-ilmiah. Sampai dengan abad 21 ini, fenomena signifikansi dan kejelasan transkultural dari olahraga menempati salah satu koridor akademis ilmiah yang membutuhkan lebih banyak penggagas dan kreator ide (Hyland, 1990).

Sekarang, signifikansi olahraga menurun di dunia Yunani, justru dengan datangnya statemenstatemen filsafat sebagai competitor cultural. Nilai penting dari tubuh dan aksi secara bertahap dikalahkan oleh tekanan pada pikiran dan refleksi intelektual. Meskipun Plato dan Aristoteles membawa nilai penting latihan fisik dalam pendidikan, namun mereka memulai revolusi intelektual yang meremehkan nilai cultural keolahragaan "remeh" justru karena katerkaitan erat olahraga dengan tubuh, aksi, perjuangan, kompetisi dan prestasi kemenangan (Hatab dalam Pramono, 2003).

Seperti dijelaskan pada bab sebelumnya bahwa aliran eksistensialisme dimana Friederich Nietzsche merupakan salah satu filsuf kontroversial yang menjadi penyumbang tidak langsung tentang kaitan pemikiran filsafat dan ilmu keolahragaan.

Perspektif naturalistik Nietzsche ini menjelaskan mengapa banyak orang menyukai permainan dan menyaksikan pertandingan olahraga, dan kenapa hal-hal tersebut dapat dianggap memiliki nilai dan manfaat yang besar. Pertunjukan atletik adalah penampilan dan proses produksi makna cultural penting. Selain itu, olahraga dapat dipahami sebagai tontonan publik yang mendramatisir keterbatasan dunia yang hidup, prestasi teatrikal dari keadaan umat manusia, pengejaran, perjuangan-perjuangan sukses dan gagal. Dari sudut pandang pengembangan sumber daya manusia, sudah jelas bahwa olahraga dapat menanamkan kebajikan-kebajikan tertentu dalam keikutsertaan disiplin, kerja tim, keberania dan intelegensi praktis (Hatab dalam Pramono, 2003).

Konsekuensi dari semua itu, permainan olahraga adalah cukup "serius” untuk diangkat ke tingkat penghargaan budaya yang lebih tinggi (Hatab dalam Pramono, 2003), sehingga filasfat mau tak mau harus berani mengkaji ulang "tradisinya" sendiri yang menekannya jiwa atas tubuh, harmoni atas konflik, dan mengakui bahwa olahraga memiliki kandungan nilai-nilai fundamental bagi keberadaan manusia. Pada dunia Yunani Kuno, lokus asal mula pemikiran filsafat Barat, olahraga tidak hanya populer, tetapi menempati penghargaan kultural terhormat.

Kecenderungan minat keilmuan yang makin ekstensif dan intensif ini membawa implikasi logis bagi filsafat untuk mengasah mata pisau keibuannya, mengingat dari sejarahnya, filsafat dianggap mater scientarum: "ibunya ilmu", dalam memberi tempat bagi pertanyaan dan jawaban mendasar atau inti isi ilmu keolahragaan sekaligus mengasuh cabang-cabang ranting ilmu keolahragaan ini. 


\section{SIMPULAN}

Meskipun ilmu olahraga merupakan ilmu yang baru diakui secara luas, namun ilmu olahraga dapat berkembang seiring kompleksitas permasalah yang ada dengan ketertarikan ilmiah ke arah yang kemapanan. Dengan berkembangnya ilmu olahraga maka Psikologi olahraga merupakan cabang ilmu baru yang diterapkan dalam bidang olahraga untuk membantu seseorang dapat menampilkan prestasi optimal, yang lebih baik dari sebelumnya. Psikologi merupakan pecahan dari filsafat. Dimana filsama dapat memberikan kerangka berpikir yang sistematis, logi, dan rasional bagi para psikolog. Dimana salah satu cabang filsafat yang mempengaruhi psikolog adalah eksistensialisme dengan tokohnya adalah Soren Kierkegaard, Friedrich Nietzsche, Victor Frankl, Jean-Paul Sartre, dan Rollo May. Eksistensialisme merupakan cabang filsafat yang mereflesikan manusia selalu bereksitensi di dalam hidupnya. Sehingga manusia dipandang sebagain individu yang selalu berproses mencari makna dan tujuan dalam hidupnya. Banyaknya pembahasan yang mencoba menyatukan disiplin ilmu untuk memaknai dasar-dasar teoretis ilmu keolahragaan sebagai ilmu baru memang sudah ada dan dalam hal digunakan sebagai bahan referensi. Meskipun banyak kontroversi mengenai ilmu keolahragaan yang dijadikan suatu ilmu yang mandiri sudah mulai surut, namun tantangan yang muncul kemudian sebagai kompensasi eksistensi ilmu keolahragaan. Dari pembahasan mengenai psikologi olahraga dan filsafat membuat penulis merasakan bahwa pentingnya mengetahui akar keilmuan psikologi olahraga dan dapat lebih mengembangkan olahraga. Selain itu lebih mengembangkan dan memperkenalkan psikologi olahraga dalam dunia olahraga di Indonesia.

\section{DAFTAR PUSTAKA}

Anshel, M. H. (1991). Dictionary of the sport and exercise sciences. Champaign, Illinois: Human Kinetics Books.

Gunarsa, S. D. (2004). Psikologi olahraga prestasi. Jakarta: BPK Gunung Mulia.

Hyland, D. A. (1990, Philosophy of sport. New York: Paragon House,.

Komisi Disiplin Ilmu Keolahragaan. (2000). Ilmu Keolahragaan dan Rencana Pengembangannya. Jakarta: Depdiknas.

Mieth, D. (1989). The ethics of sport, dalam Concilium.

Panitia Seminar dan Lokakarya Nasional Ilmu Keolahragaan. (1998). Deklarasi Ilmu Keolahragaan dan Hasil Rumusan Seminar dan Lokakarya Nasional Ilmu Keolahragaan. 6-7 September 1998. Jakarta.

Pramono, M. (2003). Dasar-dasar filosofis Ilmu Keolahragaan. Jurnal Filsafat, 34(2).

Rusli, L., \& Sumardianto. (2000). Filsafat olahraga, Depdiknas, Jakarta.

Shinabargar, N. (1989). Sexism and Sport: A Feminist Critique, dalam Concilium.

Schat, R. (1998). Nietzsche and Sport. dalam International Studies and Philosophy.

Weiss, P. (1969). Sport: A philosophy inquiry. California: Southern Illinois University Press. 